\title{
$\underline{\mathbf{P}-165}$
}

\section{An Overview of the Melissopalynological Studies in Turkey}

\author{
Munir Ozturk ${ }^{1, *}$, Riza Dalgic ${ }^{2}$, Aykut Guvensen $^{3}$ and Volkan Altay ${ }^{4}$ \\ ${ }^{I}$ Forest Facukty, University of Putra Malaysia, Selangor, Malaysia \& Botany Department, Ege University, Izmir, \\ Turkey; ${ }^{2}$ Dept. of Biochemistry, Faculty of Medicine, Ege University, Izmir, Turkey; ${ }^{3}$ Biology Department, Mustafa \\ Kemal University, Hatay, Turkey; ${ }^{4}$ Biology Dept., Faculty of Arts and Sciences, Mustafa Kemal Univ., Antakya, Turkey; \\ E-mail: munirozturk@gmail.com
}

Honey is one of the oldest known medicines used even today in folk medicine. It has been used in the treatment of wounds, burns, ulcers and also in the prevention of infection. The major antimicrobial factors determined in the honey are osmotic effect, acidity, hydrogen peroxide and plant-derived substances such as flavonoids. The total amount of pollens in the honey is one of the criteria for the selection of real honey, because the quality is correlated with the plants visited by bees. Turkey is exporting honey to many countries therefore this paper presents an overview of the pollen spectrum of honey samples in Turkey. The nectar concentration of Lamiaceae, Fabaceae, Boraginaceae and Rosaceae taxa in Turkey varies between 15-55 percent. In Izmir, Sivas, Afyon and Mugla pollen spectrum is dominated by Chenopodiaceae/Amaranthaceae, Trifolium spp., Trigonella spp., Zea mays, Anthemis spp. and Cyperaceae. These samples are more effective in the antibacterial action against Bacillus cereus, Staphylococcus aureus, Pseudomonas aeruginosa, Klebsiella pneumoniae, Morganella morganii, Micrococcus luteus, Escherichia coli and Candida albicans as compared to antibiotics. In 94 central Anatolian honey samples pollens from Astragalus, Rubus, Lapsana communis, Centaurea triumfetti, Heliotropium suaveolens, Brassica oleracea, Teucrium, Peganum harmala, Lotus, Lamium amplexicaule, Xeranthemum, Vicia cracca, Achillea and Hedysarum are dominating. In Bursa area main pollen taxa are Castanea sativa, Daucus carota, Rosa spp., Trifolium spp. and Helianthus annuus. In Denizli province dominant pollens come from Fabaceae, Castanea sativa, Lamiaceae, Apiaceae, Cistaceae and Asteraceae; whereas in Manisa and Balıkesir area pollen from the taxa Fabaceae, Brassicaceae, Cistaceae and Asteraceae are dominant. In the state of Izmir dominating major pollen spectrum belongs to Castanea sativa, Papaver, Poaceae, Vitex, Cistus, Ericaceae, Brassicaceae, Chenopodiaceae together with secondary and minor concentrations of pollens from Tilia argentea, Eucalyptus, Helianthus annuus, Daucus carota, Tribulus terrestris and Lamiaceae. The samples from West Taurus region abound in Apiaceae, Asteraceae, Fabaceae, Rubiaceae, Caryophyllaceae, Lamiaceae and Scrophulariaceae. In the States of Mugla, Izmir, Aydin, Manisa, Usak, Denizli and Canakkale dominant pollen are from Fabaceae, Asteraceae, Cistaceae, Apiaceae, Fagaceae and Lamiaceae. Total protein, invert sugar, saccharose, ash and water content in these samples varies between 0.22-1.08, 52.6-90.6, 1.14-8.05, 0.04-0.69 and 0.11-0.24 percent respectively. In the samples from East Anatolia dominant pollens belong to Fabaceae, Lamiaceae and Asteraceae. These samples show HMF: 2.2-17.3 mgr, invert suger: $62.5-90.9 \%$, saccharose: 19.6$5.90 \%$, total protein: $1.2-1.7 \%$, water: $13.4-21.5 \%$ and ash: 0.12-067 \%. In the samples from Konya dominating pollen comes from the taxa like Trifolium, Achillea, Euphorbia, Marrubium, Helianthus annuus, Vicia, Lotus, Centaurea, Medicago, Papaver, Linum, Cistus, Quercus and Faxinus. The pollen spectrum of Rize-İkizdere area is dominated by Trifolium aureum, $T$. campestre, T. pratense, Lotus corniculatus, Castanea sativa and Cynoglossum glochidiatum. 